\title{
Record of vegetation, climate change, human impact and retting of hemp in Garhwal Himalaya (India) during the past 4600 years
}

\author{
Dieter Demske,' Pavel E Tarasov,' Christian Leipe, ',2 \\ Bahadur S Kotlia, ${ }^{3}$ Lalit $M$ Joshi $^{3}$ and Tengwen Long ${ }^{1,2}$
}

\begin{abstract}
This study is focused on a $3.55-\mathrm{m}$-long sediment core retrieved from Badanital (i.e. the BT core) in 2008. Badanital $\left(30^{\circ} 29^{\prime} 50^{\prime \prime} \mathrm{N}, 78^{\circ} 55^{\prime} 26^{\prime \prime} \mathrm{E}, 2083 \mathrm{~m}\right.$ a.s.l.) is a small lake located in the upper catchment area of the Ganges in Garhwal Himalaya, northern India. The lake and the regional broad-leaved semi-evergreen forests are under the influence of the Indian Summer Monsoon (ISM) and westerly associated cyclones. Palynological investigation of the BT core revealed past vegetation changes reflecting both climate and human impact during the last 4600 years. Maximum spread of oaks occurred during c. AD 550-1100 and c. AD 1400-1630, that is, the intervals which partly overlap with the 'Medieval Warm Period' and the 'Little Ice Age', respectively. Three intervals of decreased oak pollen percentages are attributed to (I) continuously drier and cooler climatic conditions and fire activity (c. 2600-500 $B C$ ), (2) severe reduction in oak forests followed by secondary succession of alder woods (c. AD II50-1270) and (3) pre-modern settlement activities since the British imperial occupation (after c. AD 1700). We argue that the high percentages (i.e. up to $28 \%$ ) of Humulus/Cannabis type and Cannabis type pollen point to intense local retting of hemp c. 500 BC-AD 1050. Based on our age model, Cannabis fibre production at Badanital is contemporaneous with archaeological records of ancient hemp products from different parts of Eurasia suggesting possible linkages to early trade and knowledge exchange routes connecting India and the Himalaya with Central and East Asia and possibly Europe.
\end{abstract}

\section{Keywords}

age model, Cannabis, human impact, late Holocene, non-pollen palynomorphs, pollen, retting of hemp, vegetation

Received 2I November 2015; revised manuscript accepted 20 April 2016

\section{Introduction}

Garhwal and Kumaun Himalayas are densely forested regions of northern India (Forest Survey of India, 2013). The temperate and moist mountain climate, controlled by monsoonal precipitation, promotes evergreen broad-leaved oak forests, which dominate in the western Himalaya between 1500 and $3300 \mathrm{~m}$ a.s.l. (e.g. Champion and Seth, 1968; Schweinfurth, 1957; Singh and Singh, 1987). Published pollen records from Garhwal and Kumaun Himalayas indicate regionally variable climatic impacts on vegetation during the Holocene (Bhattacharyya and Chauhan, 1977; Bhattacharyya et al., 2011; Gupta, 1977, 2008; Phadtare, 2000; Phadtare and Pant, 2006; Sharma and Gupta, 1997; Trivedi et al., 2011). Isotopic records from northern Indian speleothems suggest that major climatic inferences linked to the Indian Summer Monsoon (ISM) occurred from 2250 to $1250 \mathrm{BC}$, and more recently during the 'Medieval Warm Period (MWP)' and the 'Little Ice Age (LIA)' (Kotlia et al., 2015; Phadtare and Pant, 2006; Sanwal et al., 2013). Furthermore, several pollen records show considerable impact by humans, likely through agricultural expansion, on the local vegetation after c. 1650 BC (Sharma and Gupta, 1997; Trivedi et al., 2011).

A favourable climate and rich forest resources (Singh and Rawat, 2012a, 2012b; Singh and Singh, 1987) provided good support to the Neolithic hunter-gatherer populations in Garhwal
Himalaya. Reduced precipitation after c. $2250 \mathrm{BC}$ caused a transformation of the agriculture-based Harappan Civilization, which flourished in the Greater Indus Valley since approximately 3250 $\mathrm{BC}$, ultimately leading to a migration of post-urban Harappan populations towards the Ganges valley and the foothills of the western Himalaya (Fuller and Madella, 2001; Giosan et al., 2012; Leipe et al., 2014a; Staubwasser et al., 2003). A further decrease in precipitation culminated around $1250 \mathrm{BC}$ and is associated with the continuous disappearance of traces of the Harappan Civilization from the archaeological record (Leipe et al., 2014a). Today in Garhwal Himalaya, agriculture takes place at 1000 $2200 \mathrm{~m}$ a.s.l., supplemented by semi-nomadic pastoralism at the

\footnotetext{
'Section Paleontology, Institute of Geological Sciences, Free University of Berlin, Germany

2Eurasia Department, German Archaeological Institute, Germany

${ }^{3}$ Department of Geology, Kumaun University, India
}

\section{Corresponding author:}

Pavel E Tarasov, Section Paleontology, Institute of Geological Sciences, Free University of Berlin, Malteserstr. 74-100, Building D, 12249 Berlin, Germany.

Email: ptarasov@zedat.fu-berlin.de; paveltarasov@mail.ru 


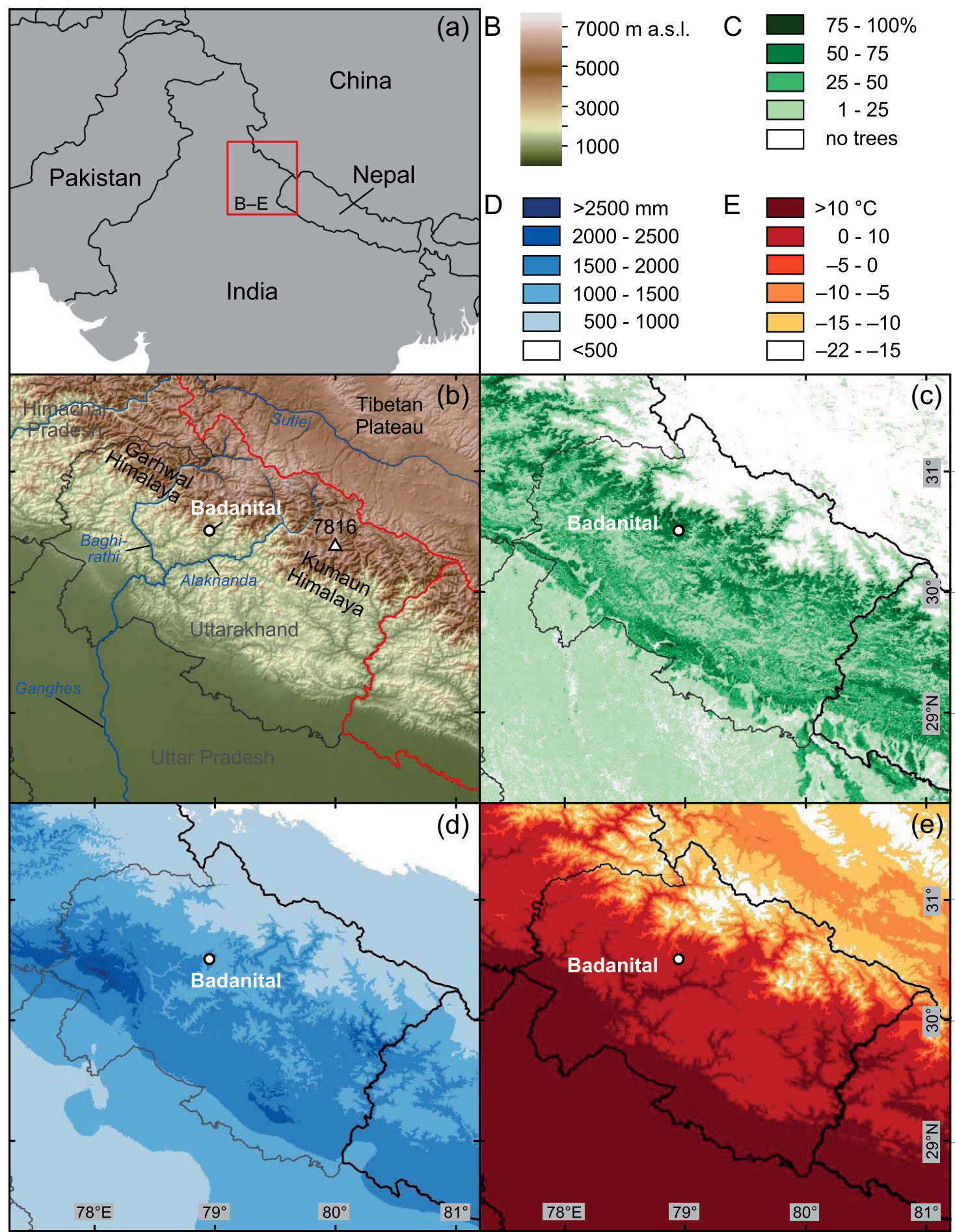

Figure I. Map compilation showing (a) the location of the study region in NW India; (b) the topographic situation (Jarvis et al., 2008) of Badanital in Garhwal Himalaya; (c) MODIS total tree cover in percent (Hansen et al., 2002); (d) mean annual precipitation in millimetre (Hijmans et al., 2005) and (e) mean temperature of the coldest month (January) in ${ }^{\circ} \mathrm{C}$ (Hijmans et al., 2005) in the study region.

higher altitudes from $1800 \mathrm{~m}$ up to $4500 \mathrm{~m}$ a.s.l. (Sharma et al., 2009; Singh and Rawat, 2012a; Singh and Singh, 1986).

The small lake Badanital is situated near the upper limit of agricultural activities in Garhwal Himalaya. Previous work on a 3.55-m sediment core from Badanital (further named the BT core) was conducted for reconstructing late-Holocene climatic changes based on geochemical parameters (Kotlia and Joshi, 2013). This paper aims to reconstruct past changes in vegetation distribution with reference to climatic and environmental forces and human activities using the palynological archive from the same core. A second goal is to discuss the evidence of local hemp retting in context of regional hemp exploitation and possible linkages to Eurasian trade networks.

\section{Modern settings}

\section{Study area}

Badanital $\left(30^{\circ} 29^{\prime} 50^{\prime \prime} \mathrm{N}, 78^{\circ} 5526^{\prime \prime} \mathrm{E}, 2083 \mathrm{~m}\right.$ a.s.1.; Figure 1a and b), sometimes referred to as Badhani Taal, is located in the outer western Himalaya and belongs to the Rudraprayag district of Garhwal Himalaya in Uttarakhand. The lake is $120 \mathrm{~m}$ long, $55 \mathrm{~m}$ wide, $2 \mathrm{~m}$ deep and has no surface outflow (Kotlia and Joshi, 2013). The watershed catchment area drains into the Lastar Gad, a southward flowing tributary of the Mandakini River, which joins the Alaknanda near Rudraprayag at $610 \mathrm{~m}$ a.s.l. Further downstream, the confluence of Alaknanda and Baghirathi marks the beginning of the Ganges. 
Tectonic movements in the study area are associated with proximity to the Jutogh Thrust. Negi (1991) and Kotlia and Joshi (2013) suggested that the lake was formed following a tectonic event. Triggered by events of excessive precipitation, landslides are also common in the disaster-prone district of Rudraprayag (Bookhagen et al., 2005; Rautela et al., 2014).

\section{Climate}

The region is influenced by the ISM and the westerlies (Scherler et al., 2010). At 1500-3000 m a.s.l., a warm-humid temperate mountain climate predominates, but microclimate conditions strongly depend on topography. The ISM brings up to $75-80 \%$ of the annual precipitation from June to September (Kotlia and Joshi, 2013) to the study region. Winters are cool and dry, though moderate-to-high snowfall associated with westerly disturbances are frequent from December to February. Meteorological data from Mandal, Chamoli District (1998-2007) demonstrate a mean annual precipitation of $2044 \mathrm{~mm}$ and strong year-to-year variability (Gairola et al., 2010; Sharma et al., 2009). The high-resolution surface climate dataset (Hijmans et al., 2005) illustrates regional variations in annual precipitation (Figure 1d) and mean temperature of the coldest month (Figure 1e) with, respectively, c. 1500 $\mathrm{mm}$ and $c .6^{\circ} \mathrm{C}$ at Badanital. In general, the Himalayas are subject to high flash rates of lightening associated with the movement of monsoonal air masses (Murugavel et al., 2014).

\section{Modern vegetation}

The major forest type of Garhwal and Kumaun Himalayas is hemi-sclerophyllous broad-leaved evergreen forest dominated by oaks (Singh and Singh, 1987). Between 1400/1800 and 2200/2400 $\mathrm{m}$ a.s.l., the vegetation communities comprise evergreen $Q u e r c u s$ leucotrichophora, Quercus floribunda and associated taxa including Abies pindrow, Rhododendron arboreum, Lyonia ovalifolia, Pyrus pashia, Litsea lanuginosa, Carpinus viminea, Alnus nepalensis and Betula alnoides (Table S1, available online). These lower Himalayan mountain ranges are characterized by a high total tree cover (Hansen et al., 2002; Figure 1c). Within a radius of $1 \mathrm{~km}$ around Badanital, tree cover ranges between $10 \%$ and $74 \%$. Oak-dominated forests occupy slopes around Badanital, while open grassland, swampy marshes and human-disturbed forest vegetation occur near the lake (Negi, 1991).

Major forest trees at 2400-3300 m a.s.1. include Quercus semecarpifolia, Acer spp. and Pinus wallichiana. Subalpine communities with Betula utilis, Rhododendron, Abies spectabilis or $Q$. semecarpifolia grow in a timberline zone at 2800-3600 m a.s.l. (Gairola et al., 2010; Rawal and Pangtey, 1994).

Between 1500 and $2200 \mathrm{~m}$ a.s.1., A. nepalensis grows naturally in oak forests (e.g. Sharma et al., 2009; Singh and Rawat, 2012b), but small patches of pure stands also occupy disturbed grounds along stream beds and around lakes (e.g. Osmaston, 1922; Singh and Singh, 1987). At lower altitudes of the western Himalaya, Pinus roxburghii forms subtropical forests ascending up to 1600$1800 \mathrm{~m}$ a.s.1., and as a component of dry oak forests commonly expands into disturbed and exploited forests (e.g. Osmaston, 1922; Singh and Singh, 1987). Hence, both A. nepalensis and $P$. roxburghii are primarily natural elements of western Himalayan forests, which may spread as pioneer trees (Hussain et al., 2008; Ohsawa et al., 1986). Similarly, Ficus (Moraceae) is common in open forest and on disturbed ruderal sites (Gairola et al., 2010; Singh and Rawat, 2012a).

\section{Human impact}

During the past centuries, forest resources of the central and western Himalaya have been strongly exploited for local and commercial purposes, including iron smelting, magnesite and limestone mining and road construction (Singh and Singh, 1987; Upreti et al., 1985). Today, local agro-pastoralists based in small villages at 1000-2200 m a.s.l. (Sharma et al., 2009; Singh and Rawat, 2012a, 2012b) contribute to exploitation and degradation of forests by collecting fuel wood, cutting trees for domestic uses and through sapling suppression from herd animal browsing (Sharma et al., 2009).

In remote mountain areas of Garhwal and Kumaun Himalayas and in western Nepal, hemp is locally cultivated for traditional multi-purpose use (Clarke, 2007a; Shah, 1997, 2004). In the eastern Himalaya, shifting cultivation or slash and burn agriculture, locally called 'jhuming', was commonly performed on land previously used by semi-nomadic people and accompanied by populations reliant upon settled agriculture (Singh and Singh, 1987).

\section{Material and methods}

\section{Core and sample processing}

The investigated BT core has a total length of $3.55 \mathrm{~m}$ and was retrieved using a piston corer in January 2008 (Kotlia and Joshi, 2013). The lithological description of the core is summarized in Table 1. Contiguous subsamples were taken in $1 \mathrm{~cm}$ slices and dried at $30^{\circ} \mathrm{C}$ for storage and transportation. Quantitative samples of 2-2.5 mg dry weight were processed using standard steps (Faegri and Iversen, 1989), including application of hydrochloric acid, potassium hydroxide, hydrofluoric acid, acetolysis and ultrasonic sieving through 7- $\mu \mathrm{m}$ meshes. Lycopodium marker spores were added, allowing for calculation of pollen and spore concentrations (Maher, 1981; Stockmarr, 1971). Coarse particles were removed by decanting, and the presence of mineral particles was noted for lithological description. The prepared samples were stored and mounted in water-free glycerol in order to prevent swelling of palynomorphs. Microscope analysis was performed on a Zeiss Axiophot at magnifications of $400 \times$ and $640 \times$ using transmission light, switching to phase contrast or Nomarski differential interference contrast when needed. At least 300 pollen grains (on average c. 400) per sample were counted.

The preservation of pollen and most of non-pollen palynomorphs was good. Algal coenobia of Pediastrum were rare and weakly preserved, suggesting partial loss during the drying process. The basic pollen sum includes terrestrial arboreal pollen (AP) and non-arboreal pollen (NAP) taxa excluding counts of aquatic taxa and non-pollen palynomorphs. Percentages were calculated on the basic sum, in case of the two excluded groups including their partial sum. The subdivision into pollen zones was based on square-root transformed percentages of terrestrial taxa using stratigraphically constrained cluster analysis by the method of incremental sum of squares (Grimm, 1987). Diagrams were created with the Tilia software package including Tilia 2.0.b.4, TiliaGraph 2.0.b.5 and TiliaGraphView 1.0.7.2 (Grimm, 1990, 2000).

\section{Determination of palynomorphs}

Pollen types were distinguished based on morphological criteria following standard references (Beug, 2004; Faegri and Iversen, 1989; Gupta and Sharma, 1986; Moore et al., 1991; Nakagawa et al., 1996; Sorsa and Huttunen, 1975; Wang et al., 1997; Zanni and Ravazzi, 2007). Pollen grains of grasses were differentiated into Poaceae wild grass type $<40 \mu \mathrm{m}$, wild grass type $>40 \mu \mathrm{m}$ and cereal type $(40-60 \mu \mathrm{m})$. The latter was distinguished from the wild grass type on the basis of annulus characteristics (Beug, 2004). Because of overlaps in morphological characteristics, the cereal type may still include pollen of some wild grass species (Beug, 2004; Gupta, 1977). The Moraceae type includes 2-5 porate pollen grains described for Morus or Ficus (Beug, 2004; Moore et al., 1991), but possibly also some badly preserved grains of Cannabaceae.

Pollen of Cannabis (hemp) type was differentiated from Humulus/Cannabis type based on morphological characteristics 
Table I. Lithological description of the BT sediment core from Badanital summarized for this study. Core segments are divided at 90 , 190 and $290 \mathrm{~cm}$. The column of carbonaceous mud shows multiple layers with embedded coarse sand (up to $2 \mathrm{~mm}$ ) and fine to medium gravel (up to $\mathrm{I} \mathrm{cm}$ size) including sub-rounded to sub-angular pebble.

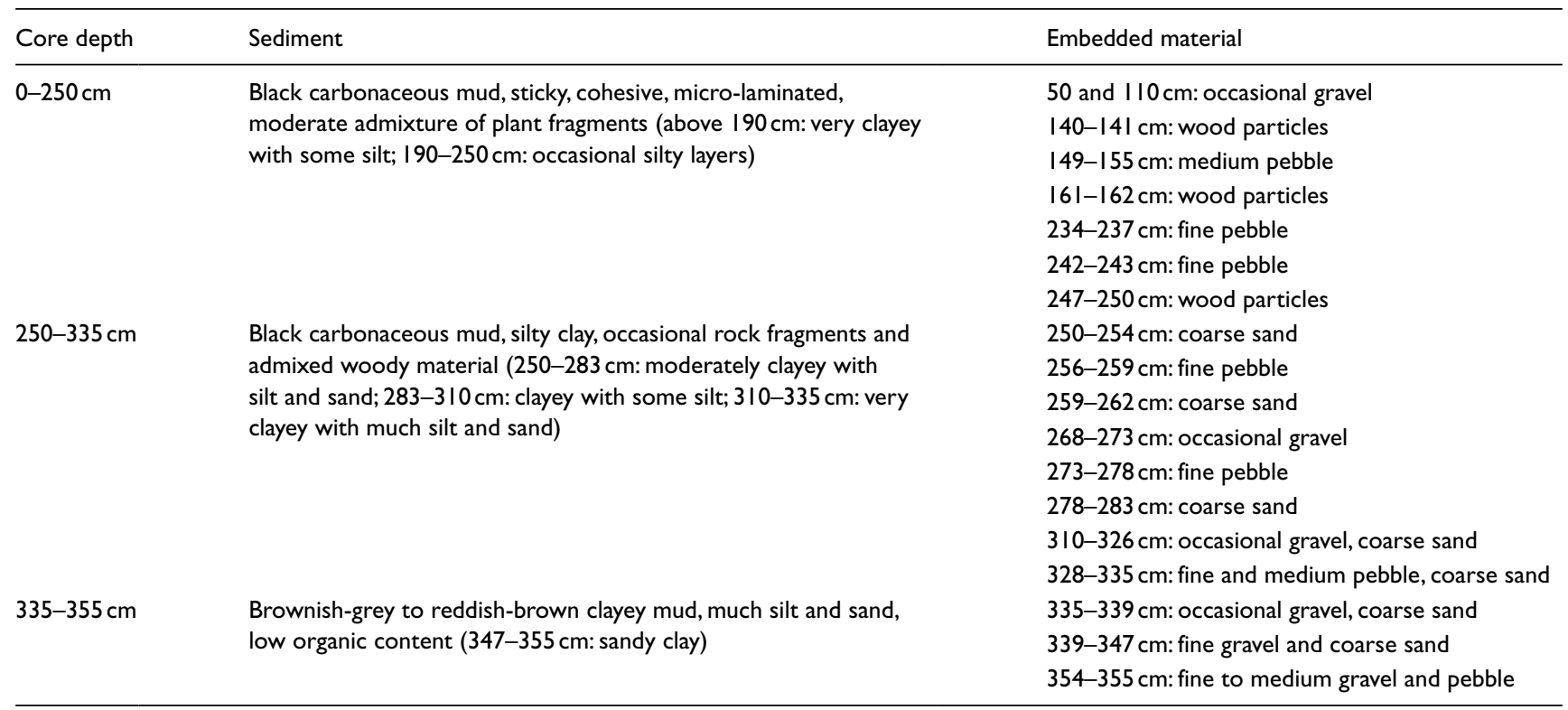

(Figure 2). While both types show typical down-bending of the tectum forming a sunken pore characteristic for Cannabaceae (Faegri and Iversen, 1989; Moore et al., 1991), pollen assigned to Cannabis type has larger size $(>27.5 \mu \mathrm{m})$ and distinctly protruding pores (e.g. Dörfler, 1990; French and Moore, 1986; Punt and Malotaux, 1984). Confusion with large Humulus (hop) pollen grains can be excluded, as associated taxa including Humulus scandens and Humulus yunnanensis occur only in eastern Eurasia (China, Korea, Japan) and in Yunnan (China), respectively (Small, 1978). Palynomorphs assigned to Humulus/Cannabis morphological type have smaller $(<27.5 \mu \mathrm{m})$ or crumpled grains, with pore protrusion being weak, concealed or non-decisive. Despite some morphological uncertainty, occurrence of hop pollen in the BT core is unlikely. Cultivated hops were introduced to northern India in the 19th century and are not regarded as native species (e.g. Shah et al., 2012). Modern records of wild Humulus lupulus in Himachal Pradesh and Uttar Pradesh (Bisht et al., 1998) might represent plants escaped from cultivation.

Pollen grains belonging to the genus Pinus were differentiated into Pinus subgen. Diploxylon and subgen. Haploxylon (Nakagawa et al., 1996; Zanni and Ravazzi, 2007), which are associated with the regionally common species of $P$. roxburghii and $P$. wallichiana (Price et al., 1998), respectively. Grains which could not be identified on subgenus level were summarized as Pinus undiff.

The recorded non-pollen palynomorphs (NPP) represent hornworts and liverworts (mosses s.l.), fern plants and allies, nonsiliceous algae and rotifers (resting eggs of Filinia and Anuraeopsis). Besides grass epidermis fragments (Ralska-Jasiewiczowa and van Geel, 1992), the counted phytoclasts include charred particles $(>50 \mu \mathrm{m})$, which were characterized by thoroughly black appearance in differentiation against brownish plant fragments and dark translucent mineral grains with a crystalline structure. Fungi were recorded as ascospores of various coprophilous taxa (van Geel et al., 2003) and chlamydospores from vasculo-arbuscular endomycorrhizal Glomus (van Geel et al., 1989).

\section{Radiocarbon dating and age modelling}

Nine samples of bulk sediment rich in organics were selected for AMS radiocarbon dating (Table 2). All conventional ${ }^{14} \mathrm{C}$ ages were calibrated using OxCal v.4.2 software package (Bronk
Ramsey, 2001). A Poisson process deposition model (Bronk Ramsey, 2008) was introduced to establish the age-depth relationship of the BT core using ${ }^{14} \mathrm{C}$ dating results and depths of the nine samples, as well as the main lithological boundaries, as key inputs. This model allows a non-uniform sedimentation rate throughout the analysed sequence. It is also found to be effective in synthesizing all available age information and in dealing with complex multi-modal age distribution after calibration (e.g. Huang et al., 2014). The model was set with a critical value of $60 \%$ and $95 \%$, respectively, for the agreement index and the convergence index. All dates leading to indices lower than the critical values were removed from the final model (Bronk Ramsey, 1995).

\section{Results}

\section{Chronology}

The uppermost date (UCIAMS-61369 at $0-1 \mathrm{~cm}$ depth, Table 2) showed an unusually high $\mathrm{F}^{14} \mathrm{C}$ value (with a calculated radiocarbon age of $-755 \pm 20{ }^{14} \mathrm{C} \mathrm{BP}$ ) and was reported as a post-bomb date (cf. Reimer et al., 2004). Bomb13NH2 curve was adopted for calibration of the date (Hua et al., 2013), which yielded a median calibrated age of AD 1999 (Table 2). This result confirmed a modern age of the sediment surface and allowed the assumption that the zero depth of the sequence can be associated with the coring time (i.e. AD 2008).

The other eight dates were calibrated using the IntCal13 curve (Reimer et al., 2013). Some dates in the upper part of the BT core do not show a clear trend of increasing age with depth (Table 2). This can be ascribed to input of older organic material caused by soil erosion (e.g. Stanley and Chen, 2000), as indicated by Glomus spores. The Poisson process model confirmed incompatibility of the four dates from 4 to $140 \mathrm{~cm}$ depth (i.e. agreement index was lower than the critical value of $60 \%$ ) to the overall age-depth relationship and removed them from the final model (Figure 3 ). Figure 3 and Table 3 demonstrate well-constrained ages and relatively narrow uncertainty ranges in the upper half of the BT core above $209 \mathrm{~cm}$. The modelled ages of the lower part of the core (below $250 \mathrm{~cm}$ ) are less robust (Table 3 ) and should be treated with caution. 

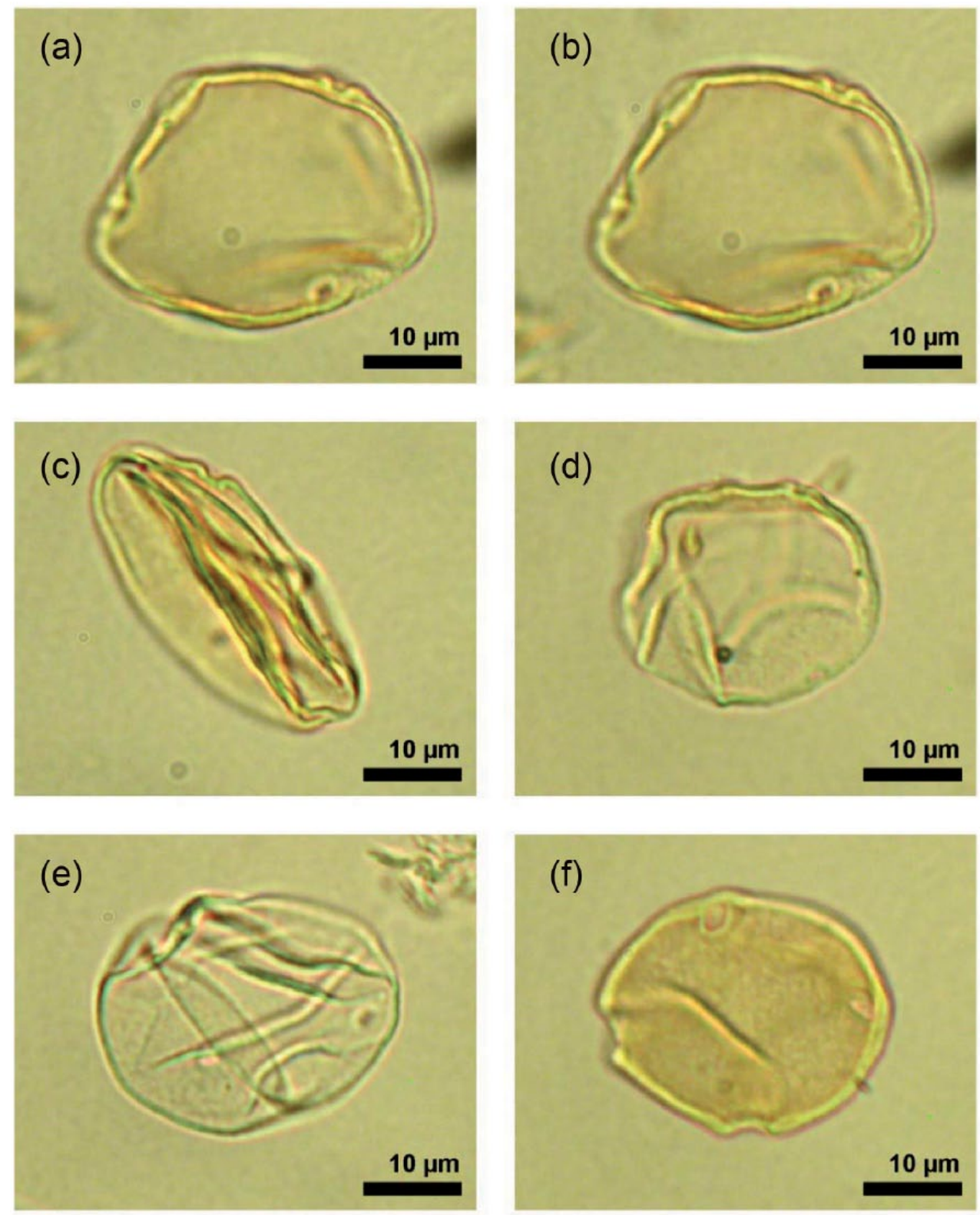

Figure 2. Pollen types of Cannabaceae and Moraceae recorded in the sediment core from Badanital (sample from 259 to $260 \mathrm{~cm}$ depth). (a, b) Cannabis type characterized by large size $(>27.5 \mu \mathrm{m})$, sunken pores, steeply rising annulus and hollow rim within annulus (slightly different focus); (c) Humulus/Cannabis type, crumpled pollen grain with weakly rising annulus; (d) Humulus/Cannabis type, slightly crumpled grain of small size $(<27.5 \mu \mathrm{m})$; (e) Humulus/Cannabis type, slightly degraded and (f) Moraceae type, four-porate grain.

Table 2. Radiocarbon AMS dating results obtained on bulk sediments from the Badanital core along with the respective calibrated ages expressed as $95 \%$ probability ranges and median point estimates (following, for example, Feranec and Kozlowski, 2016; Rull et al., 2015; Scott et al., 2007).

\begin{tabular}{|c|c|c|c|c|}
\hline $\begin{array}{l}\text { Laboratory } \\
\text { code }\end{array}$ & Core depth $(\mathrm{cm})$ & Radiocarbon date $\left({ }^{14} \mathrm{C}\right.$ yr BP $)$ & $\begin{array}{l}\text { Calibrated age, } 95 \% \\
\text { range (yr } \mathrm{AD} / \mathrm{BC} \text { ) }\end{array}$ & $\begin{array}{l}\text { Calibrated age, } \\
\text { median (yr AD/BC) }\end{array}$ \\
\hline UCIAMS-61369 & $0-1$ & Post-bomb $\mathrm{F}^{14} \mathrm{C}=1 . \mathrm{I} \pm 0.00273$ & AD 1957-2000 & AD 1999 \\
\hline Poz-43654 & $4-5$ & $615 \pm 30$ & AD I295-|40| & $A D 1349$ \\
\hline Poz-43736 & $34-35$ & $470 \pm 30$ & AD $14 \mid 0-1457$ & AD 1435 \\
\hline UCIAMS-6I370 & $67-68$ & $495 \pm 20$ & AD I4II-I443 & AD 1427 \\
\hline Poz-43655 & $99-100$ & $650 \pm 25$ & AD 1282-1393 & $A D \mid 355$ \\
\hline UCIAMS-6I377 & $137-138$ & $565 \pm 15$ & $A D|3| 8-1415$ & $A D 1349$ \\
\hline UCIAMS-6I37I & $206-207$ & $920 \pm 20$ & AD 1039-1161 & AD 1095 \\
\hline Poz-43656 & $263-264$ & $2450 \pm 30$ & $754-4 I I B C$ & $577 \mathrm{BC}$ \\
\hline Poz-43657 & $322-323$ & $3815 \pm 35$ & $2452-2 \mid 40 \mathrm{BC}$ & 2257 BC \\
\hline
\end{tabular}

The radiocarbon datings $\left({ }^{14} \mathrm{C}\right.$ yr BP) were calibrated using $\mathrm{OxCal}$ v.4.2 software. The uppermost date (UCIAMS-6I369) is reported with its $\mathrm{F}^{14} \mathrm{C}$ value (according to Reimer et al., 2004) and calibrated with BombI3NH2 calibration curve (Hua et al., 20I3). All other dates are reported with their radiocarbon age calibrated using IntCall 3 (Reimer et al., 20I3). 


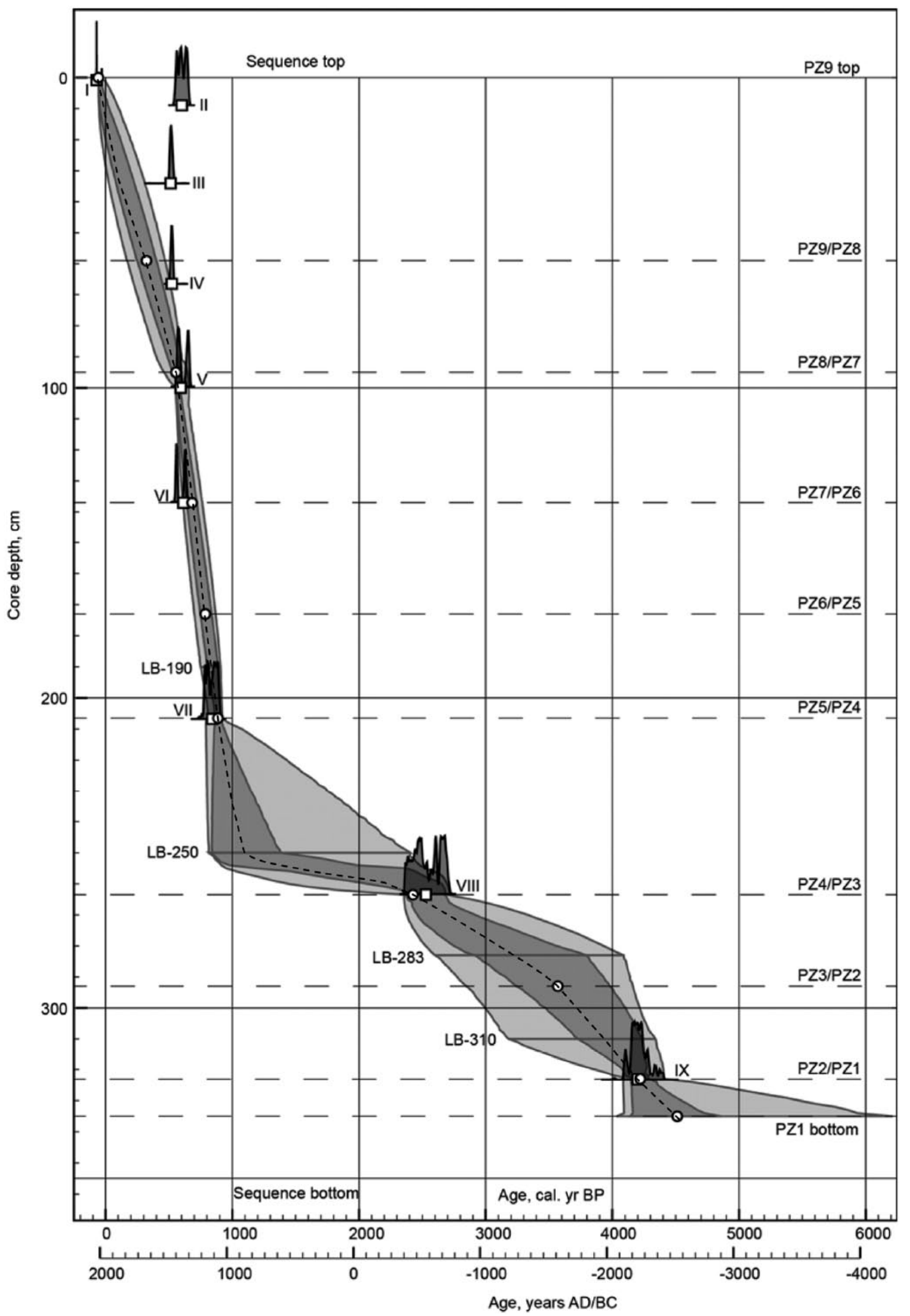

Figure 3. Age-depth model constructed for the Badanital core. The wider and lighter shade represents $95 \%$ probability distribution range, while the narrower and darker shade represents $68 \%$ probability distribution range. Open circles indicate the modelled age medians of pollen zone boundaries. Four key lithological boundaries (LB) of the BT core (see Table I for details) are also shown. Calibrated age distributions of the nine radiocarbon dates are plotted, with their calibrated medians shown in open squares. I= UCIAMS-6I 369 , II = Poz-43654, III = Poz-43736, IV = UCIAMS-6 I 370,V = Poz-43655, VI= UCIAMS-6I377, VII = UCIAMS-6 I37I, VIIII= Poz-43656, IX = Poz-43657 (see Table 2 for details).

\section{Pollen zones}

The pollen and NPP records (Figures 4 and 5) of the BT core are summarized in this section. Samples from the basal clayey layer $(355-335 \mathrm{~cm})$ with a very low pollen content and poor age control are not presented here.
Pollen zone (PZ) 1 (335-323 cm; c. 2560-2270 BC) is characterized by high percentages of Alnus and Quercus, but also Betula, Rosaceae and Abies. Taxa prevailing at lower elevations are represented by $P$. subgen. Diploxylon, Phyllanthus type and Ericaceae. The NAP types contribute less than $35 \%$. 
Table 3. The modelled age-depth relationship for pollen zone boundaries in the BT core.

\begin{tabular}{|c|c|c|c|c|}
\hline Pollen zone boundary & Core depth $(\mathrm{cm})$ & $95 \%$ range $(\mathrm{yr} A D / B C)$ & $68 \%$ range $(\mathrm{yr} A D / B C)$ & Median (yr AD/BC) \\
\hline PZ 9/PZ 8 & 59 & AD I480-1780 & $A D \mid 550-1700$ & AD 1626 \\
\hline PZ 8/PZ 7 & 95 & AD I303-1489 & $A D$ I366-1422 & AD 1394 \\
\hline PZ 7/PZ 6 & 137 & AD $1185-1340$ & AD 1229-1309 & AD 1267 \\
\hline PZ 6/PZ 5 & 173 & AD $1081-1249$ & AD III4-120I & $A D 1160$ \\
\hline PZ 5/PZ 4 & 209 & AD 928-1157 & AD 1024-1089 & AD 1053 \\
\hline PZ 4/PZ 3 & 262 & $762 \mathrm{BC}-\mathrm{AD} 126$ & $730-385$ BC & $479 \mathrm{BC}$ \\
\hline PZ 3/PZ 2 & 293 & $2212-898$ BC & $2029-129 \mid$ BC & $1617 \mathrm{BC}$ \\
\hline PZ 2/PZ I & 323 & $2457-2|4| \mathrm{BC}$ & $2337-2200 \mathrm{BC}$ & 2268 BC \\
\hline PZ I bottom & 335 & $4265-2084$ BC & $2912-2189 \mathrm{BC}$ & $2562 \mathrm{BC}$ \\
\hline
\end{tabular}

PZ 2 (323-293 cm; c. 2270-1620 BC) shows decreasing AP taxa percentages, including Alnus, $P$. subgen. Diploxylon and Abies. Moraceae type, Prunus/Sorbus type and Poaceae undiff. are more abundant in the upper part.

PZ 3 (293-262 cm; c. 1620-480 BC) reveals very low AP taxa percentages. Percentages of NAP (Caryophyllaceae, Persicaria and Poaceae undiff.) reach absolute maxima and Humulus/Cannabis type increases in abundance.

PZ 4 (262-209 cm; c. 480 BC-AD 1050) demonstrates maximum percentages of Quercus and P. subgen. Diploxylon, while Alnus and Moraceae type percentages remain relatively low. The contribution of NAP decreases moderately towards the upper zone boundary. Continuous presence of Cannabis type and high frequencies of Humulus/Cannabis type are noticeable.

PZ 5 (209-173 cm; c. AD 1050-1160) shows a gradual increase in Alnus and a sharp decline in Quercus percentages. A minor peak of Chenopodiaceae and decreasing contribution of Humulus/Cannabis type are noteworthy.

PZ 6 (173-137 cm; c. AD 1160-1270) reveals peak of Alnus (up to $60 \%$ ) and low NAP percentages. Towards the upper zone boundary, the frequencies of Rosaceae and Abies increase.

PZ 7 (137-95 cm; c. AD 1270-1400) evidences a relatively stable contribution of AP with prevailing Alnus and Quercus accompanied by increased percentages of Rosaceae. Among the NAP Polygonum type, Artemisia and pollen of Poaceae wild grass type $>40 \mu$ are abundant.

PZ 8 (59-95 cm; AD 1400-1630) records a maximum of Quercus pollen, relatively high frequencies of Betula and Rosaceae type and a decreasing contribution of $P$. subgen. Diploxylon pollen. The NAP percentages decrease significantly towards the upper zone boundary.

PZ 9 (59-0 cm; since AD 1630) is dominated by Chenopodiaceae, Artemisia and Poaceae. Although NAP values exceed 50\%, Quercus, Alnus and Rosaceae remain important AP types. Percentages of Alnus and $P$. subgen. Diploxylon increase towards the core top.

Major changes in the non-pollen palynomorphs follow the above sequence. Zones 1-3 reveal high abundance of fern spores and well-represented aquatic taxa (including Nelumbo). Resting eggs of rotifers are rare in zones 1-3, but more frequent in zone 4 . Algal remains are present throughout, but the abundance of Botryococcus is higher in zones 1-2 and 8-9. Distinct maxima of charred phytoclasts are recorded in zones 1-2, in contrast to moderately varying abundance in zones 5-9. Ascospores of coprophilous fungi are frequent in zones 4, 7 and 9, but nearly absent in zones 1-3 and 8. Glomus chlamydospores show increased abundance in zones 7-9.

\section{Interpretation and discussion}

In this study, we focus on changes in the forest cover caused by climatic and anthropogenic factors. The record reveals an interval with high percentages of Cannabis pollen, therefore we also discuss the use of hemp fibres in the Himalayan region and possible linkages to Eurasian trade networks.

\section{Forest development}

The pollen record reveals the regional forest history since c. 2560 BC. Since the lake catchment and pollen source areas are relatively small, the reconstruction represents a confined part of Garhwal Himalaya. By c. 2560-2270 BC (PZ 1), forest around Badanital was dominated by oaks and alders with an admixture of diverse evergreen (e.g. Myrtaceae, Grewia, Strobilanthes type, Symplocos) and deciduous taxa (Rosaceae, Betula, Carpinus, Juglans, Ulmus, Acer), including various shrubs (Corylus, Myrica, Lonicera) and ferns (Polypodiales, Pteris type, Pteridium). Abundant alder trees indicate soil disturbance, possibly reflecting increased fluvial activities at riverside habitats, as suggested by the varying content of mineral matter in the sediments. The dense forest cover including warm-temperate and subtropical taxa points to warm and humid climatic conditions. The presence of Nelumbo (water lotus), which at lower altitudes of Nainital persisted throughout the Holocene (Gupta, 1977), also points to warmer conditions.

Declining contribution of alder woods and the spread of grasses indicate a severely disturbed forest cover after c. 2270 BC. Increasing abundance of Moraceae type (including Morus, Ficus) also indicates greater forest openness or patchiness. The decline of oak, alder and pine forests and spread of open vegetation communities (Poaceae, Persicaria and Caryophyllaceae) culminated between $c$. 1620-480 BC (PZ 3).

The reduction in forest vegetation can be ascribed to a climatic deterioration after 2300 BC. Corresponding vegetation changes ascribed to the $4.2 \mathrm{ka}$ event and a transition to cooler and drier conditions were reconstructed from pollen records across Garhwal and Kumaun Himalayas (Gupta, 2008; Phadtare, 2000; Sharma and Gupta, 1997; Trivedi et al., 2011). The late-Holocene weakening of the ISM and North Atlantic centennial-scale cooling episodes strongly affected environments in the Himalayas (e.g. Leipe et al., 2014a, 2014b). This climatic development culminated in a dry interval around 3.2 ka (Kotlia et al., 2015) leading to severe forest reduction in Garhwal Himalaya as evidenced by PZ 3 (Figure 4).

Forest disturbance was aggravated by local fires as indicated by the record of large-sized $(>50 \mu \mathrm{m})$ charred phytoclasts (Figure 5). The regional occurrence of fires during the second millennium $\mathrm{BC}$ may be explained by drier climatic conditions and increased lightning frequency under the weakened ISM. Charcoal was noted also in other pollen sequences from Garhwal and Kumaun Himalayas (Gupta, 1977), but, at least in part, ascribed to human impact (Sharma and Gupta, 1997).

After c. $480 \mathrm{BC}$, oak forests recovered forming stable communities with a low contribution of alders under improving climatic conditions. The optimum development of dense oak forests occurred about 480 BC-AD 1050 (PZ 4). This interval overlaps in time with the 'MWP' in the West Himalayas dated to $c$. AD 8301160 (Sanwal et al., 2013) or to $c$. AD 750-1450 (Kotlia et al., 


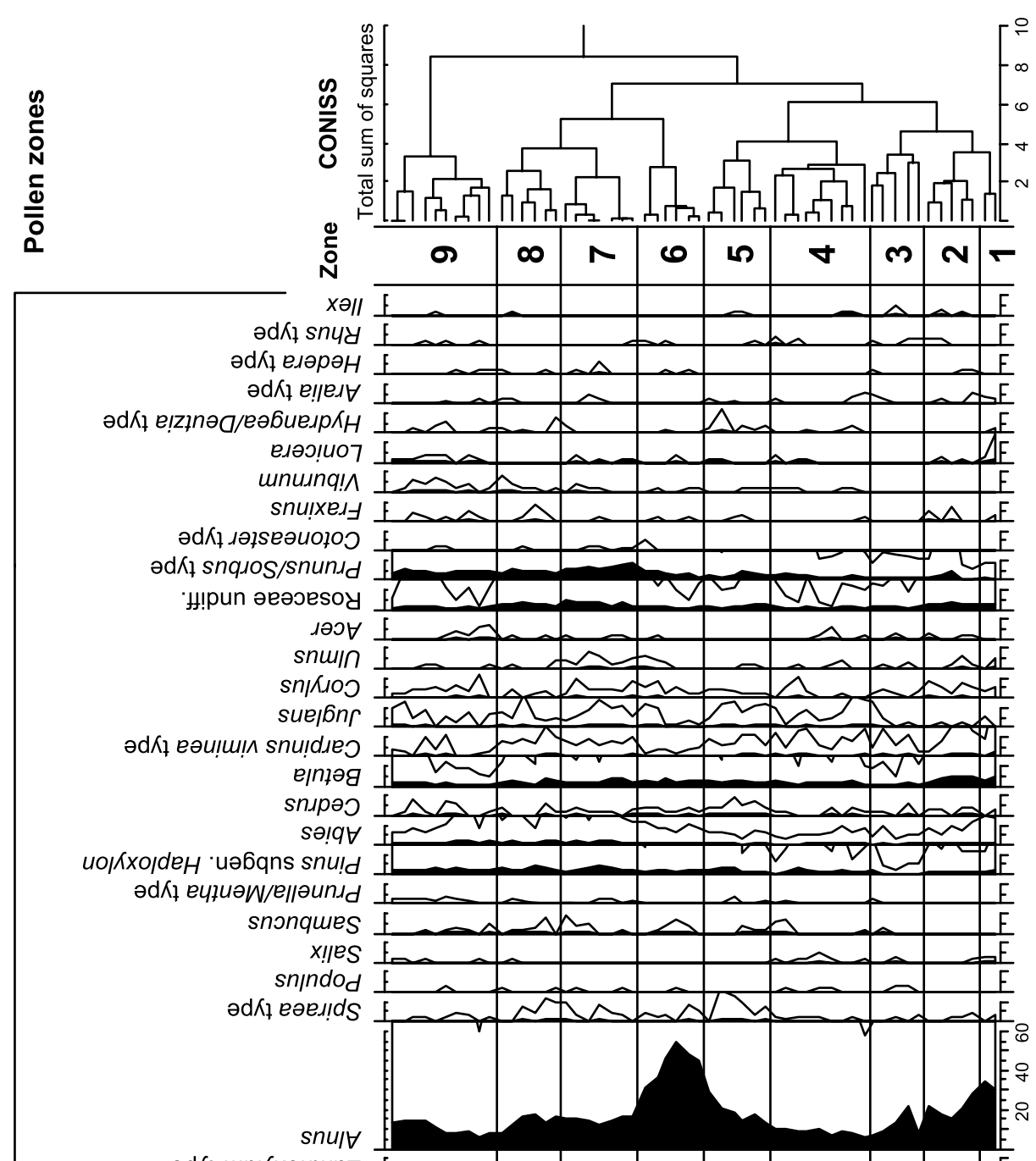




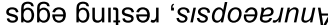
s66ə 6u!nsa 'e!lu!!!

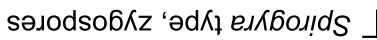

unıse!pәd '†

snoวo⿰oหifog

әdK

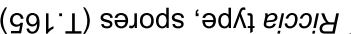
әdא⿵

әdК รоләэочни

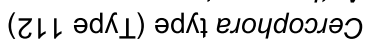

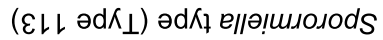

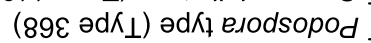

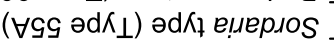

Nan $\cdots$ तn

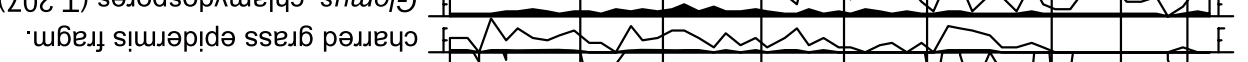

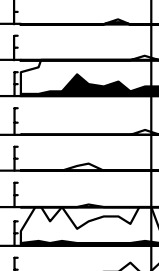

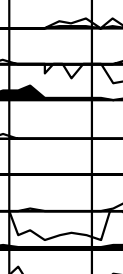

\section{舟}

$\frac{\infty}{2}$

urlos< 'mbent әnss!! ұue|d рәмецчо

unukdobe

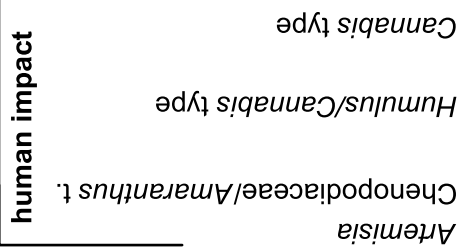

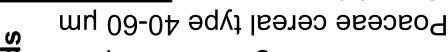

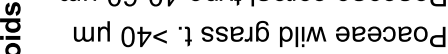

url 0t> 7 sse.16 p!!m әвәэеод

产

әеәэеләdКว

әdК

'H!pun әеәэеие!ฺนәכ

f

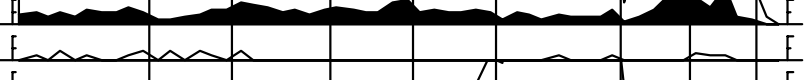

(n)
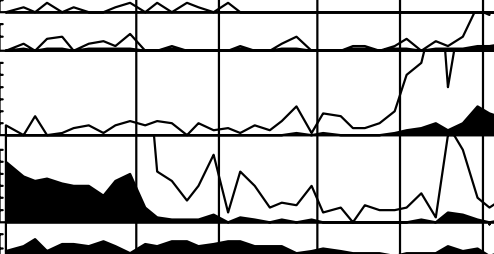

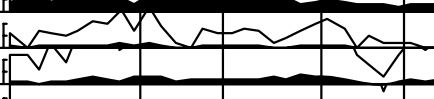

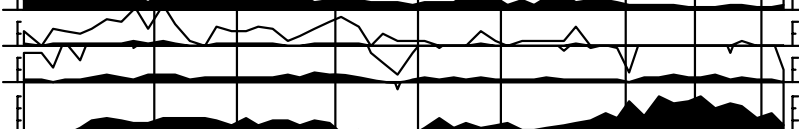

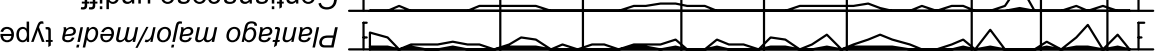

әеәэеэ!

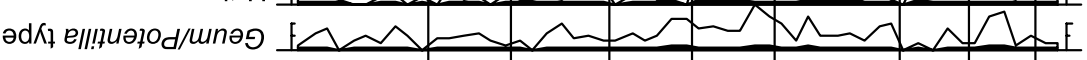

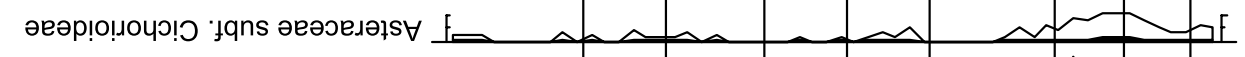

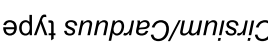

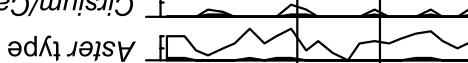

suə!ledmi tr

号

əd $K_{7}$ un!!ाes

unıวग!|ечц

峞

әd $\hat{K}_{7}$ ełns.u!

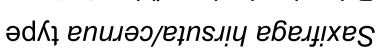

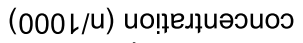

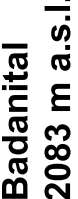

əגods pue uə\|І0d

(யง) чұdəa
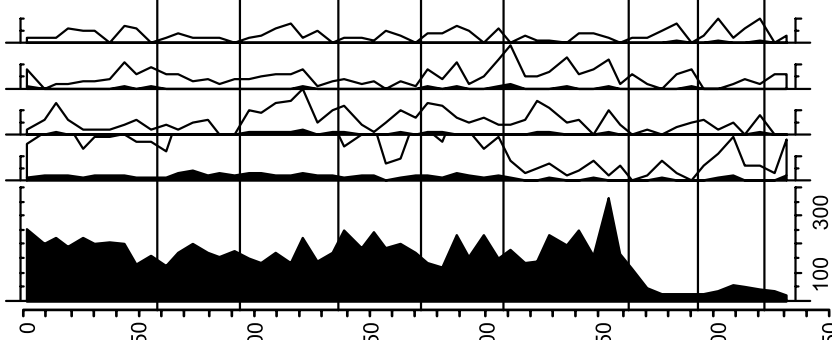

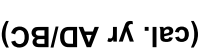

ә6 $\forall$

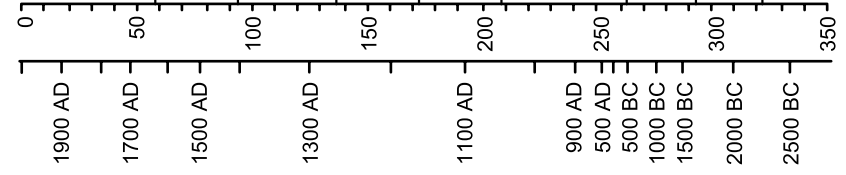


2015). Vegetation changes reflecting climatic warming are also recorded at several sites in Garhwal and Kumaun Himalayas (Phadtare and Pant, 2006; Trivedi et al., 2011) and adjacent Himachal Himalaya (Chauhan, 2006). Slightly increased frequencies of coprophilous fungi spores indicate moderate grazing activities around Badanital. The pollen record of Cannabis type and Humulus/Cannabis type (PZ 4) suggests considerable human impact on the lake ecosystem during this time interval.

A severe reduction in oak forests accompanied by a spread of alder, other deciduous trees (Juglans, Betula), shrubs (Spiraea type, Hydrangeaceae) and Pinus subgen. Haploxylon started during PZ 5. Additionally, a spread in Abies, a mid to high mountain forest element, is indicated. The enormous expansion of alder woods recorded in PZ 6 (c. AD 1160-1270) points to heavy disturbance of forest habitats, which might be caused by various environmental factors including soil erosion, climatic deterioration and/or human impact. Erosion as the major factor can be excluded, because the recorded input of coarse mineral grains (Table 1) follows the Alnus pollen maximum. An interval of dry climate dated to AD 1250-1450 (Sanwal et al., 2013) could possibly influence the forest development and human activities, but a severe drought at this time is unlikely and does not appear in the regional vegetation and moisture reconstructions (Leipe et al., 2014a, 2014b). Hence, the changes in vegetation reconstructed between $c$. AD 1050 and 1270 (PZ 5 and 6) can be explained by initial anthropogenic disturbance (e.g. cutting of trees, pasture or small-scale agriculture), subsequent abandonment of the area and successional development of alder vegetation.

After c. AD 1270 (PZ 7-9), the vegetation cover was relatively stable. In general, open oak forests with a still considerable contribution of alder and a variety of Rosaceae (Pyrus, Prunus, Sorbus, Rubus, Cotoneaster) covered the area under warm and humid climatic conditions. During $c$. AD 1390-1630 (PZ 8), oak forests again expanded. Furthermore, the reduced contribution of $P$. subgen. Diploxylon pollen points to some decrease in warm-temperate Pinus species (e.g. P. roxburghii) growing at lower altitudes. As indicators of grazing and human impact are weak, the spread of oak forests (likely $Q$. semecarpifolia) is attributed to cooler climatic conditions during the 'LIA' interval (Bookhagen and Burbank, 2006; Sanwal et al., 2013; Sharma and Owen, 1996). For the study region, different 'LIA' time ranges including $c$. AD 1440-1880 (Sanwal et al., 2013), c. AD 1450-1750 (Kotlia et al., 2013) and AD 1510-1790 (Kotlia and Joshi, 2013) have been suggested. Corresponding changes in regional vegetation ascribed to the 'LIA' are reported from other sites in the western Himalaya (Chauhan, 2006; Phadtare and Pant, 2006). Severe reduction in forest and a parallel spread of Chenopodiaceae around Badanital documents settlement activities during the past $c .300$ years.

\section{Vegetation disturbance and human impact}

Generally, weak representation of pollen types indicating human impact between c. 2560 and $480 \mathrm{BC}$ (PZ 1-3) supports the interpretation that predominantly natural factors were driving regional vegetation development. However, human-induced environmental changes in the wider study region may be expected after c. 2000 BC when late- and post-Harappan migrants reached the more humid areas of the western Himalayan foothills and the Yamuna-Ganges interfluve (Fuller, 2006; Giosan et al., 2012; Leipe et al., 2014a). In the early first millennium BC, people of the Painted Grey Ware (PGW) culture brought large-scale cultivation to the upper Jamuna-Ganges valley (Lal, 1992), in part linked to Early Iron Age sites on the central Gangetic plains (Singh, 2008; Tewari, 2003). Wood remains of Himalayan $P$. roxburghii were found at Jakhera/ Atranjikhera on the Gangetic plains, possibly pointing to the penetration of PGW culture people into Garhwal Himalaya along the Ganges and/or across convenient passes (Lal, 1992; Tewari, 2003). There are also a few archaeological records documenting human activities in the study region prior to $c$. $500 \mathrm{BC}$. In the region of Kumaun Himalaya, an iron smelting site at Uleni (Almora district) was dated to c. 1022-826 BC (Singh, 2008), and in Tehri Garhwal, a contemporary PGW site was discovered (Lal, 1992). The only evidence for human deforestation activities may come from increased concentrations of charred plant fragments recorded in PZ 2 and 3 (c. 2270-480 BC). However, such interpretation remains highly hypothetical, since increased fire activity could have been also naturally induced by lightning.

Between $480 \mathrm{BC}$ and AD 1050 (PZ 4), moderate grazing activities are indicated by the record of ascospores from fungi growing on animal dung (Figure 5). Low pollen percentages of Urticaceae, Brassicaceae and Artemisia also suggest occasional browsing of the area by people and the use of forests as seasonal grazing grounds. The record of individual pollen grains of Fagopyrum (buckwheat), however, does not provide conclusive evidence for cultivation of this grain crop. Low abundance of Chenopodiaceae pollen (in comparison to the uppermost PZ 9) does not indicate a local sedentary human population in the forests around Badanital. In contrast to moderate disturbance of terrestrial vegetation indicated by increased herb pollen concentration, the lake itself was subject to considerable human impact. The high pollen concentrations of Cannabis type and Humulus/Cannabis type suggest that local populations used Badanital for water retting of hemp.

Around AD 1050-1100 (lower PZ 5), moderate disturbances in oak forests were likely associated with a short settlement phase, which is indicated by increased pollen frequencies of ruderal Chenopodiaceae. Scarce occurrence of dung fungi points to weak grazing activities, suggesting dense forest cover and limited grazing grounds around the lake. The subsequent decline in oak forest recorded in the upper PZ 5 (c. AD 1100-1160) possibly reflects forest clearing by pastoralists in an attempt to gain more grazing land. In historical context, the oak forest destruction phase at Badanital dates to the late Buddhist-Hindu period in northern India. At the same time, the decrease in pollen associated with Cannabis and the increase in Alnus pollen during PZ 5 point to a continuous reduction in hemp processing and a successional growth of alder on the disturbed forest sites, respectively.

Our record suggests that human impact was absent around the lake during PZ 6 (c. AD 1160-1270). This is indicated by maximum spread of pioneer alder communities during the first half $(c$. AD 1160-1200), which were gradually replaced by regenerating oak during the second half (c. AD 1200-1270). In addition, pollen related to retting reaches low concentrations suggesting that hemp processing was given up. The phase of abandonment at Badanital during this interval corresponds to a historical period marked by conflict, which faced Mongol attacks, taxation and confiscations by early dynasties of the Delhi Sultanate, and resulting rebellions (Walsh, 2006).

The vegetation development between AD 1270 and 1390 (PZ 7) is characterized by stable, though rather open oak forests. A slight increase in Pteridium, Rumex and Polygonum type and Artemisia percentages (Figure 5) may be attributed to weak disturbances caused by humans. Increased abundance of Glomus and hornwort mosses (Anthoceros type) indicates soil disturbances, while spores of coprophilous fungi point to moderate seasonal grazing activities around Badanital. Increased frequencies of Poaceae pollen $>40 \mu \mathrm{m}$ suggest enhanced agricultural activities in the broader region, but do not provide conclusive evidence for grain cultivation.

The spread of oak forests and low frequencies of charred plant fragments between $c$. AD 1390 and 1630 (PZ 8) correspond to reduced vegetation disturbance, low human impact and weak 
grazing activities. One speculative reason for this abandonment of the area could be annual taxes based on crops introduced by the Mughal Empire (AD 1526-1707). This so-called tax-farming finally contributed to the break-down of the Mughal fiscal system (Walsh, 2006).

Large-scale deforestation during the past $c .300$ years coincides with a rapid expansion of ruderal vegetation, dominated by Chenopodiaceae communities, the presence of cultivated plants (cereals, buckwheat and hemp) and a spread of Brassicaceae, Polygonum and Artemisia. The foundation (and/or expansion) of Badhani village likely occurred before commencement of the British imperial period (AD 1757-1947). An increase in the abundance of charred particles, hornwort spores and coprophilous fungi points to moderate vegetation disturbances. Hence, human activities likely represent similar strategies to those used in the region today, with herders migrating to higher altitudes in the summer months.

A spread of alder and pine forests likely coincides with the First War of Indian Independence (AD 1857-1858), followed by direct rule of the British Crown (Walsh, 2006). It is likely that the commercialization of agriculture, combined with low competitiveness of mountain peasants, caused abandonment of agricultural land and forest recovery at Badanital.

\section{Evidence of hemp exploitation and retting from northern India and Eurasia}

The palynological sequence from Badanital revealed an interval of high percentages of Cannabis type and Humulus/Cannabis type. In pollen records from European lakes, percentage values of $20-30 \%$ for both types (variations between $8-10 \%$ and 80 $90 \%$ ) are interpreted as an indicator of water retting of hemp (Edwards and Whittington, 1990, 1992; Kittel et al., 2014; Lavrieux et al., 2013; Mercuri et al., 2002; Schofield and Waller, 2005). Retting is a microbial process facilitating the release of bast fibres from bundled hemp stalks submersed in adequately shallow water (Clarke, 2007a; Dörfler, 1990; French and Moore, 1986). Dated to AD 900-1860, the exceptional record of both hemp pollen and sedimentary cannabinol from Lake Aydat (Massif Central, France) clearly documents the local practice of retting (Lavrieux et al., 2013). Remarkably, the pollen percentages in the Aydat and Badanital records are similarly high. Considering continuous representation of Cannabis type (up to 8\%) and maximum percentages of Humulus/Cannabis type (above $8 \%$ ), the confidential interval of intense retting at Badanital can be dated from c. $480 \mathrm{BC}$ to $\mathrm{AD} 1050$. High loss on ignition (LOI) values reported in the corresponding BT core section (Kotlia and Joshi, 2013) point to increased amounts of organic matter and corroborate an external input by retting activities. Between $c$. $1300 \mathrm{BC}$ and $\mathrm{AD} 1150$ values of $3-28 \%$ are recorded, though dominated by Humulus/Cannabis type pollen (2-20\%). Excluding past growth of Humulus in the study area, the initial increase in frequencies of Humulus/Cannabis type after c. $1300 \mathrm{BC}$ could point to a spread of wild hemp plants, early hemp cultivation and/or the beginning of retting at Badanital.

In southwest Asia, the use of fibres in general dates back well before 7000-6000 BC (Fuller, 2008). It is likely that Cannabis entered India via Himalayan trade routes about 3000 years ago (Fleming and Clarke, 1998). Archaeological records suggest an early use of hemp and various fibre plants in northern India during the first millennium BC or even earlier. At Senuwar in the middle Ganges region, fossil remains of Linum usitatissimum point to the use of flax fibres $c .1300-600 \mathrm{BC}$, whereas findings of Cannabis seeds are considered weak evidence for its use as a fibre crop (Fuller, 2008). At Narhan in Uttar Pradesh, flax seeds and fibres of ramie (Boehmeria, Urticaceae) were dated to $c$. 1300-800 BC (Fuller, 2008). At this time, the PGW culture people inhabiting river-banks used ramie-fibre nets for fishing (Lal, 1992). Literary records (e.g. the Atharveda texts) suggest the use of Cannabis in India since about 1200-1000 BC (Booth, 2003; Touw, 1981).

Intense retting of hemp at Badanital took place between c. 480 $\mathrm{BC}$ and $\mathrm{AD} 1050$. According to archaeological evidence, this time interval corresponds to intensified human mobility, interaction and trade across northern India along the major rivers. During $c$. 600-300 BC, the Uttarapatha was a major trading network along the Indo-Gangetic plain connecting the northwestern India ports on the Bay of Bengal with northern side routes towards the upper and middle Ganges region (Singh, 2008). In the Mauryan Empire (322-185 BC), the Ganges valley was a 'hub for trade routes', while immigration areas of the Yuezhi tribes (200 BC-AD 300) can be considered as a 'crucible of trade' (Walsh, 2006). The Kushan Empire (AD 78-144) controlled Indian routes connected to the Silk Road network (Walsh, 2006) during the early first millennium AD. During the reign of the Gupta empire (AD 320550 ), fibre products of silk, cotton, flax and hemp were widely distributed in India (Randhawa, 1980). During the 7th-11th century $\mathrm{AD}$, hemp products were available as mats, cloth and textiles including imports from the Tang dynasty in China (Randhawa, 1980). Historical records of the 9th-11th century AD report on hemp fields and hempen yarns produced in India (Walsh, 2006). Traditional processing of hemp fibres, including the retting technique, is still widely distributed in the Kumaun and Garhwal Himalayas (Kuddus et al., 2013; Mathur and Joshi, 2013; Pant and Samant, 2010; Shah, 1997, 2004; Shah and Joshi, 1971) and in Nepal (Clarke, 2007a).

Early cultivation of hemp at Badanital could be linked to records of hemp seeds in the burial caves of Mebrak in Nepal Himalaya located at 3000-3500 m a.s.l. Since c. 1000 BC, the Kali Gandhaki gorge was an important trade route connecting the Tibetan Plateau with the lower Ganges valley, thus linking India with Xinjiang and Central Asia (Alt et al., 2003; Knörzer, 2000). At the Jhong site, macrobotanical remains of several grain crops were found, including seeds of Cannabis dated between $400 \mathrm{BC}$ and AD 200 (Knörzer, 2000). The fossil hemp at the Jhong site is thought to be imported, because evidence for present-day traditional cultivation in the area is lacking (Knörzer, 2000). The nearby Muktinath site of the Himalayan mummies revealed finely woven textiles made of cotton, wool and linen or other plant fibres including mixed fabrics and a pair of trousers, which point to advanced techniques of textile processing between $400 \mathrm{BC}$ and AD 50 (Alt et al., 2003).

The fossil hemp seeds from the Mebrak sites corroborate increased frequencies of Humulus/Cannabis type and appearance of Cannabis type pollen at Badanital. This may tentatively suggest that hemp was widely known and locally used across the West and Central Himalayas since $c$. 500 BC. The assumed import of hemp to the Kali Gandhaki sites (Knörzer, 2000) could point to regional trade and connections with the north, but possibly also with the Garhwal Himalaya.

The decline of hemp fibre production at Badanital occurred within a few decades. One possible explanation is that hemp production was subject to the competitive import of silk and hemp from China during the Tang dynasty (Randhawa, 1980). Furthermore, retting of hemp eventually deteriorates limnic environments, poisons fish and prevents the lake to be used as a potable water source (Edwards and Whittington, 1990). This scenario, however, remains purely hypothetical and cannot be accepted without further proof. Hence, we suggest that the disappearance of the short-lasting settlement at Badanital and the end of retting activities may have been caused by a combination of environmental and socioeconomic factors, which forced people to abandon the area.

The presented record from Badanital raises more general questions concerning the primary origin of retting techniques 
applied to hemp. Only a few Asian pollen records potentially point to early retting sites. In eastern Asia, palynological evidence is severely hampered by the fact that Humulus scandens and Cannabis pollen have similar size ranges. At the Seonam-dong site in South Korea up to $25 \%$ and $50 \%$ of Humulus/Cannabis pollen were assigned to the use of hemp as an agricultural crop during 3150-400 BC and AD 200-950, respectively (Park et al., 2013). High percentages of Humulus type pollen, possibly including Cannabis, were noted at the Banpo site (Shaanxi Province) dated to 4115-3535 BC, associated with cloth imprints in ceramic (Fleming and Clarke, 1998; Li, 1974). A sedimentary sequence from the Yangtze lowlands in eastern China revealed high frequencies of Moraceae type pollen since c. 3000 BC (Innes et al., 2014). However, the wide pollen category comprising Moraceae s.l. allowed for different interpretations, either reflecting secondary trees of Moraceae in open woodlands or retting of Cannabis for fibres (Innes et al., 2014). Except these references, we are not aware of further pollen sites potentially documenting retting of hemp in China or Korea.

As the chronological and regional evaluation of retting activities and ancient hemp fibre products in Asia are beyond the scope of this paper, we refer the reader to more comprehensive studies (e.g. Clarke and Merlin, 2013; Fleming and Clarke, 1998; Lu and Clarke, 1995; Merlin, 2003; Touw, 1981). Because the records of hemp from Badanital and Nepal may suggest early linkages to East and Central Asian trade routes, some selected examples with direct evidence of ancient cloth and textiles are pointed out below. In Korea traces of hemp thread, chord and cloth are reported from the Goongsan and a Gojoseon site dated to c. $3000 \mathrm{BC}$ and 2333108 BC, respectively (Clarke, 2006). In China, weaving of hemp cloth dates back to the Shang dynasty in the second millennium BC (Booth, 2003; Li, 1974). Funerary hemp textiles associated with the Shang dynasty were detected at the Anyang and Changsha cemeteries (c. 1520-1030/685 BC) (Fleming and Clarke, 1998; Merlin, 2003). In Shaanxi province, a fragment of tightly woven hemp cloth was found in a grave of the late Western Zhou dynasty (Li, 1974; Merlin, 2003), and in Henan province, a pair of hemp trousers were excavated from a royal Guo tomb of the Western Zhou (1046-771 BC) (Beck et al., 2014). The Yanghai Tombs in Xinjiang revealed Cannabis seeds, which were dated to c. 750-550 BC and tentatively assigned to C. indica (Jiang et al., 2006; Mukherjee et al., 2008; Russo et al., 2008). Furthermore, Cannabis fibres were detected in decorative tails of horse figurines from the Astana graves in Xinjiang dated between the 3rd and 9th century AD (Chen et al., 2014).

European records for hemp fibre use are not as old as those from Asia. In southern Italy, retting of hemp was established during the first century AD (Mercuri et al., 2002). The oldest Scandinavian record of hemp retting from Sweden is of a similar age (Larsson and Lagerås, 2015). In Denmark, the water retting technique was known at least since $800 \mathrm{BC}$, being initially applied to flax and by AD 375-1000 also to hemp (Andresen and Karg, 2011). Possibly, the oldest European record of woven hemp cloth from the Celtic grave at Hochdorf, near Stuttgart, Germany, is dated to $c$. 550 BC (Körber-Grohne, 1985, 1987), hence predating pollen evidence for retting sites in Europe (Dörfler, 1990; Larsson and Lagerås, 2015; Mercuri et al., 2002; Rösch, 1999). However, the Hochdorf cloth was shown to be made from unretted or not fully processed hemp fibres (Banck-Burgess, 1999; KörberGrohne, 1985). Remarkably, fibres directly peeled from the stalks are sometimes also used in modern traditional processing of hemp in Nepal, Vietnam, Korea and China (Clarke, 1995, 2006, 2007a, 2007b) and similar techniques are known in Europe (Ottich, 2006).

General knowledge on ancient use of hemp fibres, whether unretted or retted, for making textiles is still fragmentary. The cultural diffusion of hemp towards Europe probably progressed along westward routes from Central Asia or further south from southwest Asia eventually reaching the Mediterranean (Dörfler, 1990; Fleming and Clarke 1998; Mercuri et al., 2002; Merlin, 2003). Badanital possibly represents the earliest retting site for hemp in India and might provide a missing link in the Eurasian history of ancient retting techniques.

\section{Conclusion}

The palynological sequence from Badanital documents the 4600-year-long vegetation history of Garhwal Himalaya. The most severe forest disturbances between $c .2270$ and $480 \mathrm{BC}$ are attributed to climatic deterioration and natural fires. Another phase of deforestation is linked to the settlement and human activities over the past three centuries. Under moderate human impact on vegetation, a dense forest developed during $c$. AD 480-1050. A decline of oak forests, secondary succession of alders (c. AD 1160-1270) and subsequent regeneration of oak forest were associated with a dry interval and abandonment of the area. During $c$. AD 1390-1630, oak forests were able to spread again, as human impact was weak.

The pollen record from Badanital also provides evidence for local use of hemp implying cultivation of hemp since $c$. 1300/1000 $\mathrm{BC}$ and water retting between $480 \mathrm{BC}$ and $\mathrm{AD} 1050 / 1160$. Thus, Badanital represents the first Indian and one of the oldest Eurasian records documenting local water retting of hemp. Relating pollen evidence from Badanital to historical accounts and archaeological sites, Garhwal Himalaya was likely linked to a network of trade routes across the Indo-Gangetic plain, first along the Uttarapatha routes and later connected to the Silk Road trade network via the Himalayan Kali Gandhaki route in Nepal.

Considering the still fragmentary knowledge on ancient Eurasian retting sites and textiles, the pollen record from Badanital should provide incentives for further palynological studies contributing to the history of hemp. Geochemical analyses of sedimentary cannabinol as a biomarker would be most important in areas of eastern Asia, where taxonomic differentiation using pollen analysis seems to be problematic. Furthermore, existing archaeological records of hempen products leave open several questions concerning the ancient use of hemp fibres and the temporal/spatial diffusion of water retting technique across Eurasia.

\section{Acknowledgements}

We are grateful to the anonymous reviewers for valuable comments and to Dr R Spengler for language polishing and first critical reading of the manuscript.

\section{Funding}

This work contributes to the interdisciplinary 'Silk Road Fashion' research project (01UO1310) financed by the German Federal Ministry of Education and Research (BMBF) and to the 'Bridging Eurasia' initiative supported by the German Archaeological Institute (DAI) and German Research Foundation (DFG TA 540/5). B. Kotlia is thankful to the Ministry of Earth Sciences (MoES/43/ Geosci), India, for financial support. T. Long acknowledges a postdoctoral fellowship granted by the Fritz Thyssen Foundation (Germany)

\section{References}

Alt KW, Burger J, Simons A et al. (2003) Climbing into the past - First Himalayan mummies discovered in Nepal. Journal of Archaeological Science 30(11): 1529-1535.

Andresen S and Karg S (2011) Retting pits for textile fibre plants at Danish prehistoric sites dated between 800 B.C. and A.D. 1050. Vegetation History and Archaeobotany 20(6): 517-526.

Banck-Burgess J (1999) Hochdorf IV: Die Textilfunde aus dem späthallstattzeitlichen Fürstengrab von Eberdingen-Hochdorf 
(Kreis Ludwigsburg) und weitere Grabtextilien aus hallstattund latènezeitlichen Kulturgruppen. Forschungen und Berichte zur Vor- und Frühgeschichte in Baden-Württemberg 70. Stuttgart: Theiss, $294 \mathrm{pp}$.

Beck U, Wagner M, Li X et al. (2014) The invention of trousers and its likely affiliation with horseback riding and mobility: A case study of late 2nd millennium BC finds from Turfan in eastern Central Asia. Quaternary International 348: 224-235.

Beug HJ (2004) Leitfaden der Pollenbestimmung. München: Pfeil, $542 \mathrm{pp}$.

Bhattacharyya A and Chauhan MS (1977) Vegetational and climatic changes during recent past around Tipra Bank Glacier, Garhwal Himalaya. Current Science 72(6): 408-412.

Bhattacharyya A, Ranhotra PS and Gergan JT (2011) Vegetation vis-à-vis climate and glacier history during 12,400 to $5,400 \mathrm{yr}$ BP from Dokriani valley, Garhwal Himalaya, India. Journal of the Geological Society of India 77(5): 401-408.

Bisht GS, Anthwal PA and Kumar A (1998) Agricultural economy of the Bhotiyas of Garhwal: Status and potentialities. In: Pande DC (ed.) Managing Agriculture for a Better Tomorrow: The Indian Experience. New Delhi: M.D. Publications Pvt. Ltd, pp. 291-300.

Bookhagen B and Burbank DW (2006) Topography, relief, and TRMM-derived rainfall variations along the Himalaya. Geophysical Research Letters 33(8): L08405.

Bookhagen B, Thiede RC and Strecker MR (2005) Late Quaternary intensified monsoon phases control landscape evolution in the northwest Himalaya. Geology 33(2): 149-152.

Booth M (2003) Cannabis: A History. London: Doubleday, 448 pp.

Bronk Ramsey C (1995) Radiocarbon calibration and analysis of stratigraphy: The OxCal program. Radiocarbon 37(2): 425-430.

Bronk Ramsey C (2001) Development of the radiocarbon calibration program. Radiocarbon 43(2A): 355-363.

Bronk Ramsey C (2008) Deposition models for chronological records. Quaternary Science Reviews 27: 42-60.

Champion HG and Seth SK (1968) A Revised Survey of the Forest Types of India. New Delhi: Government of India Publication Division, pp. 404.

Chauhan MS (2006) Late Holocene vegetation and climate change in the alpine belt of Himachal Pradesh. Current Science 91(11): 1562-1567.

Chen T, Yao S, Merlin M et al. (2014) Identification of Cannabis fiber from the Astana Cemeteries, Xinjiang, China, with reference to its unique decorative utilization. Economic Botany 68(1): 59-66.

Clarke RC (1995) Hemp (Cannabis sativa L.) cultivation in the Tai'an District of Shandong Province, Peoples Republic of China. Journal of the International Hemp Association 2(2): $57-65$.

Clarke RC (2006) Hemp (Cannabis) cultivation and use in the Republic of Korea. Journal of Industrial Hemp 11(1): 51-86.

Clarke RC (2007a) Traditional Cannabis cultivation in Darchula District, Nepal: Seed, resin and textiles. Journal of Industrial Hemp 12(2): 19-42.

Clarke RC (2007b) Traditional Nepali Hemp textiles. Journal of Industrial Hemp 12(2): 97-113.

Clarke RC and Merlin MD (2013) Cannabis: Evolution and Ethnobotany. Berkeley, CA: University of California Press, pp. 452.

Dörfler W (1990) Die Geschichte des Hanfanbaus in Mitteleuropa aufgrund palynologischer Untersuchungen und von Großrestnachweisen. Prähistorische Zeitschrift 65(2): 218-244.

Edwards KJ and Whittington G (1990) Palynological evidence for the growing of Cannabis sativa L. (hemp) in medieval and historical Scotland. Transactions of the Institute of British Geographers 15(1): 60-69.
Edwards KJ and Whittington G (1992) Male and female plant selection in the cultivation of hemp, and variations in fossil Cannabis pollen representation. The Holocene 2(1): 85-87.

Faegri K and Iversen J (1989) Textbook of Pollen Analysis. 4th edn. Chichester: John Wiley \& Sons, 328 pp.

Feranec RS and Kozlowski AL (2016) Implications of a Bayesian radiocarbon calibration of colonization ages for mammalian megafauna in glaciated New York State after the Last Glacial Maximum. Quaternary Research 85: 262-270.

Fleming MP and Clarke RC (1998) Physical evidence for the antiquity of Cannabis sativa L. (Cannabaceae). Journal of the International Hemp Association 5(2): 80-92.

Forest Survey of India (2013) India State of Forest, report 2013. Dehradun: Ministry of Environment \& Forests. pp. 252 pp. Available at: http://fsi.nic.in (accessed 07 July 2015).

French CN and Moore PD (1986) Deforestation, Cannabis cultivation and Schwingmoor formation at Cors Llyn (Llyn Mire), Central Wales. New Phytologist 102(3): 469-482.

Fuller DQ (2006) Agricultural origins and frontiers in South Asia: A working synthesis. Journal of World Prehistory 20: 1-86.

Fuller DQ (2008) The spread of textile production and textile crops in India beyond the Harappan zone: An aspect of the emergence of craft specialization and systematic trade. In: Osada T and Uesugi A (eds) Linguistics, Archaeology and the Human Past, Occasional Paper 3. Kyoto: Indus Project, Research Institute for Humanity and Nature, pp. 1-26.

Fuller DQ and Madella M (2001) Issues in Harappan archaeobotany: Retrospect and prospect. In: Settar S and Korisettar R (eds) Indian Archaeology in Retrospect. Protohistory, vol. II. New Delhi: Manohar, pp. 317-390.

Gairola S, Sharma CM, Rana CS et al. (2010) Phytodiversity (Angiosperms and Gymnosperms) in Mandal-Chopta Forest of Garhwal Himalaya, Uttarakhand, India. Nature and Science 8(1): 1-17.

Giosan L, Clift PD, Macklin MG et al. (2012) Fluvial landscapes of the Harappan civilization. Proceedings of the National Academy of Sciences 109(26): E1688-E1694.

Grimm EC (1987) CONISS: A FORTRAN 77 program for stratigraphically constrained cluster analysis by the method of incremental sum of squares. Computers \& Geosciences 13(1): 13-35.

Grimm EC (1990) TILIA and TILIA-GRAPH: PC Speadsheet and graphics software for pollen data. INQUA Working Group on Data-Handling Methods Newsletter 4: 5-7.

Grimm EC (2000) TGView and Tilia for Windows. INQUA SubCommission on Data-Handling Methods Newsletter 20: 5.

Gupta A (2008) Late Quaternary vegetation and climate from temperate zone of the Kumaun Himalaya, India (with remarks on neotectonic disturbance). Acta Palaeobotanica 48(2): 325-333.

Gupta HP (1977) Pollen analytical reconnaissance of post glacial deposits from subtropical zone in Naini Tal district, Kumaon Himalaya. The Palaeobotanist 24(3): 215-244.

Gupta HP and Sharma C (1986) Pollen Flora of North-West Himalaya. Lucknow: Indian Association of Palynostratigraphers, pp. 29; 181.

Hansen MC, DeFries RS, Townshend JRG et al. (2002) Towards an operational MODIS continuous field of percent tree cover algorithm: Examples using AVHRR and MODIS data. Remote Sensing of Environment 83(1-2): 303-319.

Hijmans RJ, Cameron SE, Parra JL et al. (2005) Very high resolution interpolated climate surfaces for global land areas. International Journal of Climatology 25: 1965-1978.

Hua Q, Barbetti M and Rakowski AZ (2013) Atmospheric radiocarbon for the period 1950-2010. Radiocarbon 55(4): 2059-2072.

Huang X, Oberhänsli H, von Suchodoletz H et al. (2014) Hydrological changes in western Central Asia (Kyrgyzstan) during 
the Holocene as inferred from a palaeolimnological study in lake Son Kul. Quaternary Science Reviews 103: 134-152.

Hussain MS, Sultana A, Khan JA et al. (2008) Species composition and community structure of forest stands in Kumaon Himalaya, Uttarakhand, India. Tropical Ecology 49(2): 167-181.

Innes JB, Zong Y, Wang Z et al. (2014) Climatic and palaeoecological changes during the mid- to Late Holocene transition in eastern China: High-resolution pollen and non-pollen palynomorph analysis at Pingwang, Yangtze coastal lowlands. Quaternary Science Reviews 99: 164-175.

Jarvis A, Reuter HI, Nelson A et al. (2008) Hole-filled SRTM for the globe, version 4. Available at: http://srtm.csi.cgiar.org (accessed 21 July 2015).

Jiang H-E, Li X, Zhao Y-X et al. (2006) A new insight into Cannabis sativa (Cannabaceae) utilization from 2500-year-old Yanghai Tombs, Xinjiang, China. Journal of Ethnopharmacology 108(3): 414-422.

Kittel P, Muzolf B, Płóciennik M et al. (2014) A multi-proxy reconstruction from Lutomiersk-Koziówki, Central Poland, in the context of early modern hemp and flax processing. Journal of Archaeological Science 50: 318-337.

Knörzer K-H (2000) 3000 years of agriculture in a valley of the High Himalayas. Vegetation History and Archaeobotany 9(4): 219-222.

Körber-Grohne U (1985) Die biologischen Reste aus dem hallstattzeitlichen Fürstengrab von Hochdorf, Gemeinde Eberdingen (Kreis Ludwigsburg). In: Körber-Grohne U and Küster H (eds) Forschungen und Berichte zur Vor-und Frühgeschichte in Baden-Württemberg 19. Stuttgart: Theiss, pp. 85-265.

Körber-Grohne U (1987) Nutzpflanzen in Deutschland: Kulturgeschichte und Biologie. Stuttgart: Theiss, pp. 490.

Kotlia BS and Joshi LM (2013) Late Holocene climatic changes in Garhwal Himalaya. Current Science 104(7): 911-919.

Kotlia BS, Singh AK, Joshi LM et al. (2015) Precipitation variability in the Indian Central Himalaya during last ca. 4,000 years inferred from a speleothem record: Impact of Indian Summer Monsoon (ISM) and Westerlies. Quaternary International 371: 244-253.

Kuddus M, Ginawi IAM and Al-Hazimi A (2013) Cannabis sativa: An ancient wild edible plant of India. Emirates Journal of Food and Agriculture 25(10): 736-745.

Lal BB (1992) The Painted Grey Ware culture of the Iron Age. In: Dani AH and Masson VM (eds) History of Civilizations of Central Asia 1: The Dawn of Civilization: Earliest Times to 700 B.C. Paris: UNESCO Publishing, pp. 412-431.

Larsson M and Lagerås P (2015) New evidence on the introduction, cultivation and processing of hemp (Cannabis sativa L.) in southern Sweden. Environmental Archaeology 20(2): $111-119$.

Lavrieux M, Jacob J, Disnar J-R et al. (2013) Sedimentary cannabinol tracks the history of hemp retting. Geology 41(7): 751-754.

Leipe C, Demske D and Tarasov PE (2014a) A Holocene pollen record from the northwestern Himalayan lake Tso Moriri: Implications for palaeoclimatic and archaeological research. Quaternary International 348: 93-112.

Leipe C, Demske D, Tarasov PE et al. (2014b) Potential of pollen and non-pollen palynomorph records from Tso Moriri (TransHimalaya, NW India) for reconstructing Holocene limnology and human-environmental interactions. Quaternary International 348: 113-129.

Li H-L (1974) An archaeological and historical account of Cannabis in China. Economic Botany 28(4): 437-448.

$\mathrm{Lu} \mathrm{XZ}$ and Clarke RC (1995) The cultivation and use of hemp (Cannabis sativa L.) in ancient China. Journal of the International Hemp Association 2: 26-30.
Maher LJ (1981) Statistics for microfossil concentration measurements employing samples spiked with marker grains. Review of Palaeobotany and Palynology 32(2-3): 153-191.

Mathur A and Joshi H (2013) Ethnobotanical studies of the Tarai Region of Kumaun, Uttarakhand, India. Ethnobotany Research \& Applications 11: 175-203.

Mercuri AM, Accorsi CA and Bandini Mazzanti M (2002) The long history of Cannabis and its cultivation by the Romans in central Italy, shown by pollen records from Lago Albano and Lago di Nemi. Vegetation History and Archaeobotany 11(4): 263-276.

Merlin MD (2003) Archaeological evidence for the tradition of psychoactive plant use In the old world. Economic Botany 57(3): 295-323.

Moore PD, Webb JA and Collinson ME (1991) Pollen Analysis. 2nd Edition. Oxford: Blackwell, 216 pp.

Mukherjee A, Roy S, De Bera S et al. (2008) Results of molecular analysis of an archaeological hemp (Cannabis sativa L.) DNA sample from North West China. Genetic Resources and Crop Evolution 55(4): 481-485.

Murugavel P, Pawar SD and Gopalakrishan V (2014) Climatology of lightning over Indian region and its relationship with convective available potential energy. International Journal of Climatology 34(11): 3179-3187.

Nakagawa T, Yasuda Y and Tabata H (1996) Pollen morphology of Himalayan Pinus and Quercus and its importance in palynological studies in Himalayan area. Review of Palaeobotany and Palynology 91(1-4): 317-329.

Negi SS (1991) Himalayan Rivers, Lakes and Glaciers. New Delhi: Indus Publishing Company, 182 pp.

Ohsawa M, Shakya PR and Numata M (1986) Distribution and succession of West Himalayan forest types in the eastern part of the Nepal Himalaya. Mountain Research and Development 6(2): 143-157.

Osmaston AE (1922) Notes on the forest communities of the Garhwal Himalaya. The Journal of Ecology 10(2): 129-167.

Ottich I (2006) Hanf. In: Ottich I (ed.) Ein Buch von alten Fasern. 2nd Edition, pp. 18-24. Available at: http://www. dorisdiedrich.de/spindel/Faserbuch_pflanzen.pdf (accessed 1 October 2015).

Pant S and Samant SS (2010) Ethnobotanical observations in the Mournaula Reserve Forest of Kumoun, West Himalaya, India. Ethnobotanical Leaflets 14: 193-217.

Park J, Kim M, Lim HS et al. (2013) Pollen and sediment evidence for late-Holocene human impact at the Seonam-dong archeological site, Gwangju, Korea. Review of Palaeobotany and Palynology 193: 110-118.

Phadtare NR (2000) Sharp decrease in summer monsoon strength 4000-3500 cal yr B.P. in the central higher Himalaya of India based on pollen evidence from Alpine Peat. Quaternary Research 53(1): 122-129.

Phadtare NR and Pant RK (2006) A century-scale pollen record of vegetation and climate history during the past 3500 years in the Pinder Valley, Kumaon Higher Himalaya, India. Journal of Geological Society of India 68: 495-506.

Price RA, Liston A and Strauss SH (1998) Phylogeny and systematics of Pinus. In: Richardson DM (ed.) Ecology and Biogeography of Pinus. Cambridge: Cambridge University Press, pp. 49-68.

Punt W and Malotaux M (1984) Cannabaceae, Moraceae and Urticaceae. Review of Palaeobotany and Palynology 42(1): 23-44.

Ralska-Jasiewiczowa M and van Geel B (1992) Early human disturbance of the natural environment recorded in annually laminated sediments of Lake Gościaż, central Poland. Vegetation History and Archaeobotany 1: 33-42. 
Randhawa MS (1980) A History of Agriculture in India I: Beginning to the 12th Century. New Delhi: Indian Council of Agricultural Research, 542 pp.

Rautela P, Sajwan KS, Khanduri S et al. (2014) Geological Investigations in Rudraprayag District with Special Reference to Mass Instability. Dehradun: Disaster Mitigation and Management Centre, 106 pp. Available at: dmmc.uk.gov.in/files/pdf/ Rudraprayag_final.pdf (accessed 27 October 2015).

Rawal RS and Pangtey YPS (1994) Distribution and structuralfunctional attributes of trees in the high altitude zone of Central Himalaya, India. Vegetatio 112: 29-34.

Reimer PJ, Brown TA and Reimer RW (2004) Discussion: Reporting and calibration of post-bomb ${ }^{14} \mathrm{C}$ data. Radiocarbon 46(3): 1299-1304.

Reimer PJ, Bard E, Bayliss A et al. (2013) IntCal13 and MARINE13 radiocarbon age calibration curves $0-50,000$ years cal BP. Radiocarbon 55(4): 1869-1887.

Rösch M (1999) Hanf: Botanik, Archäologie. In: Beck H, Geuenich D, Steuer H et al. (eds.) Reallexikon der Germanischen Altertumskunde Band 13. 2nd Edition. Berlin: De Gruyter, pp. 630-631.

Rull V, Cañellas-Boltà N, Margalef O et al. (2015) Late-Holocene vegetation dynamics and deforestation in Rano Aroi: Implications for Easter Island's ecological and cultural history. Quaternary Science Reviews 126: 219-226.

Russo EB, Jiang H-E, Li X et al. (2008) Phytochemical and genetic analyses of ancient cannabis from Central Asia. Journal of Experimental Botany 59(15): 4171-4182.

Sanwal J, Kotlia BS, Rajendran C et al. (2013) Climatic variability in Central Indian Himalaya during the last $\sim 1800$ years: Evidence from a high resolution speleothem record. Quaternary International 304: 183-192.

Scherler D, Bookhagen B, Strecker MR et al. (2010) Timing and extent of late Quaternary glaciation in the western Himalaya constrained by ${ }^{10} \mathrm{Be}$ moraine dating in Garhwal, India. Quaternary Science Reviews 29(7-8): 815-831.

Schofield JE and Waller MP (2005) A pollen analytical record for hemp retting from Dungeness Foreland, UK. Journal of Archaeological Science 32(5): 715-726.

Schweinfurth U (1957) Die horizontale and vertikale Verbreitung der Vegetation im Himalaya. Bonner Geographische Abhandlungen 20: 1-273.

Scott EM, Cook GT and Naysmith P (2007) Error and uncertainty in radiocarbon measurements. Radiocarbon 49: 427-440.

Shah NC (1997) Ethnobotany of Cannabis sativa in Kumaun region, India. Ethnobotany 9: 117-121.

Shah NC (2004) Indigenous uses and ethnobotany of Cannabis sativa L. (Hemp) in Uttaranchal (India). Journal of Industrial Hemp 9(1): 69-77.

Shah NC and Joshi MC (1971) An ethnobotanical study of the Kumaon Region of India. Economic Botany 25(4): 414-422.

Shah MA, Reshi ZA and Lavoie C (2012) Predicting plant invasiveness from native range size: Clues from the Kashmir Himalaya. Journal of Plant Ecology 5(2): 167-173.

Sharma C and Gupta A (1997) Vegetation and climate in Garhwal Himalaya during Early Holocene: Deoria Tal. Palaeobotanist 46(3): 111-116.

Sharma CM, Gairola S, Ghildiyal SK et al. (2009) Forest resource use patterns in relation to socioeconomic status: A case study in four temperate villages of Garhwal Himalaya, India. Mountain Research and Development 29(4): 308-319.

Sharma MC and Owen LA (1996) Quaternary glacial history of NW Garhwal, Central Himalayas. Quaternary Science Reviews 15(4): 335-365.
Singh G and Rawat GS (2012a) Depletion of Oak (Quercus spp.) Forests in the Western Himalaya: Grazing, Fuelwood and Fodder collection. In: Okia CA (ed.) Global Perspectives on Sustainable Forest Management. Rijeka: InTech, pp. 29-42. Available at: http://www.intechopen.com/books/global-perspectives-on-sustainable-forest-management (accessed 9 July 2015).

Singh G and Rawat GS (2012b) Quantitative analysis of tree species diversity in different oak (Quercus spp.) dominated forests in Garhwal Himalaya, India. Notulae Scientia Biologicae 4(4): 132-140.

Singh JS and Singh SP (1987) Forest vegetation of the Himalaya. The Botanical Review 53(1): 80-192.

Singh SP and Singh JS (1986) Structure and function of the Central Himalayan oak forests. Proceedings of the Indian Academic of Sciences 96(3): 159-189.

Singh U (2008) A History of Ancient and Early Medieval India: From the Stone Age to the 12th Century. New Delhi: Dorling Kindersley, $677 \mathrm{pp}$.

Small E (1978) A numerical and nomenclatural analysis of morpho-geographic taxa of Humulus. Systematic Botany 3(1): $37-76$.

Sorsa P and Huttunen P (1975) On the pollen morphology of the Urticaceae. Annales Botanici Fennici 12(4): 165-182.

Stanley DJ and Chen Z (2000) Radiocarbon dates in China's Holocene Yangtze Delta: Record of sediment storage and reworking, not timing of deposition. Journal of Coastal Research 16(4): 1126-1132.

Staubwasser M, Sirocko F, Grootes PM et al. (2003) Climate change at the $4.2 \mathrm{ka}$ BP termination of the Indus valley civilization and Holocene south Asian monsoon variability. Geophysical Research Letters 30(8): 1425.

Stockmarr J (1971) Tablets with spores used in absolute pollen analysis. Pollen et Spores 13: 615-621.

Tewari R (2003) The origins of iron-working in India: New evidence from the Central Ganga Plain and the Eastern Vindhyas. Antiquity 77(297): 536-545.

Touw M (1981) The religious and medicinal uses of cannabis in China, India and Tibet. Journal of Psychoactive Drugs 13(1): 23-34.

Trivedi A, Kotlia BS and Joshi LM (2011) Mid-Holocene vegetation shifts and climate change in the temperate belt of Garhwal Himalaya. The Palaeobotanist 60: 291-298.

Upreti N, Tewari JC and Singh SP (1985) The oak forests of the Kumaun Himalaya (India): Composition, diversity, and regeneration. Mountain Research and Development 5(2): 163-174.

van Geel B, Coope GR and van der Hammen T (1989) Palaeoecology and stratigraphy of the Lateglacial type section at Usselo (the Netherlands). Review of Palaeobotany and Palynology 60(1-2): 25-129.

van Geel B, Buurman J, Brinkkemper O et al. (2003) Environmental reconstruction of a Roman Period settlement site in Uitgeest (The Netherlands), with special reference to coprophilous fungi. Journal of Archaeological Science 30(7): 873-883.

Walsh JE (2006) A Brief History of India. New York: Infobase Publishing, $348 \mathrm{pp}$.

Wang F, Chien N, Zhang Y et al. (1997) Pollen Flora of China. 2nd Edition. Beijing: Science Press, 461 pp., 205 plates.

Zanni M and Ravazzi C (2007) Description and differentiation of Pseudolarix amabilis pollen: Palaeoecological implications and new identification key to fresh bisaccate pollen. Review of Palaeobotany and Palynology 145(1-2): 35-75. 